\title{
Comparison of the Effect of Vermicompost and Inorganic Fertilizers on Vegetative Growth and Fruit Production of Tomato (Solanum lycopersicum L.)
}

\author{
Md. Abul Kashem*, Ashoka Sarker, Imam Hossain, Md. Shoffikul Islam \\ Department of Soil Science, University of Chittagong, Chittagong, Bangladesh \\ Email: *kashem00@yahoo.com
}

Received 18 January 2015; accepted 3 February 2015; published 5 February 2015

Copyright (C) 2015 by authors and Scientific Research Publishing Inc.

This work is licensed under the Creative Commons Attribution International License (CC BY). http://creativecommons.org/licenses/by/4.0/

\section{(c) (i) Open Access}

\section{Abstract}

This study attempted to compare the effect of cow manure vermicompost and inorganic fertilizers on the vegetative growth and fruits of tomato plant (Solanum lycopersicum L.). An air dried sandy loam soil was mixed with five rates of vermicompost equivalent to 0 (control), 5, 10, 15 and $20 \mathrm{t}$ $\mathrm{ha}^{-1}$ and three rates of NPK fertilizer equivalent to $50 \%\left(\mathrm{~N}-\mathrm{P}-\mathrm{K}=69-16-35 \mathrm{~kg} \mathrm{ha}^{-1}\right), 100 \%(\mathrm{~N}-\mathrm{P}-\mathrm{K}=$ 137-32-70 $\mathrm{kg} \mathrm{ha}^{-1}$ ) and 200\% (N-P-K = 274-64-140 $\left.\mathrm{kg} \mathrm{ha}^{-1}\right)$. The treatments were replicated three times. The data revealed that shoot length, number of leaves, dry matter weight of shoots and roots, fruit number and fruit weight were influenced significantly $(P<0.05)$ by the application of vermicompost and NPK fertilizer in the growth media. The highest dose of vermicompost of $20 \mathrm{t}$ ha $^{-1}$ increased dry weight of shoot of 52 folds and root of 115 folds, number of fruit(s)/plant of 6 folds and mean fruit weight of 29 folds while the highest rate of NPK fertilizer of $200 \%$ increased dry weight of shoot of 35 folds and root of 80 folds, number of fruit(s)/plant of 4 folds and mean fruit weight of 18 folds over the control treatment. The growth performance of tomato was better in the vermicompost amended soil pots than the plants grown in the inorganic fertilizer amended soil pots. This study suggested that the vermicompost served as a potential source of nutrients for plant growth.

\section{Keywords}

Vermicompost, NPK Fertilizer, Tomato, Growth, Yield

\footnotetext{
"Corresponding author.
}

How to cite this paper: Kashem, M.A., Sarker, A., Hossain, I. and Islam, M.S. (2015) Comparison of the Effect of Vermicompost and Inorganic Fertilizers on Vegetative Growth and Fruit Production of Tomato (Solanum lycopersicum L.). Open Journal of Soil Science, 5, 53-58. http://dx.doi.org/10.4236/ojss.2015.52006 


\section{Introduction}

Application of chemical fertilizers in the crop field contributes greatly to the deterioration of the environment, loss of soil fertility, less agricultural productivity and soil degradation [1]. The price of chemical fertilizers is very high and sometimes it is not available in the market as well for which the farmers sometimes fail to apply these fertilizers to the crop field in time. Compare to inorganic fertilizer, organic manure is readily available to the farmers and the price is also low [2]. In addition to that, application of manure may reduce the environmental pollution that is caused while manufacturing the chemical fertilizers in the industry [3].

It is a well known fact that organic fertilizers supply nutrients to the plants in adequate amount for optimum growth of plant and may increase the uptake of nutrients, assimilation capacity and the hormonal activity [4] [5]. Cow manure vermicompost could be used as an excellent soil amendment for main fields and nursery beds and has been reported to be useful in raising nursery species plants [6]. Vermicomposting means the use of earthworms for composting organic residues. Earthworms can eat as much as their own body weight per day. It is estimated that 1000 tons of moist organic manure can be converted into 300 tons of compost by earthworms [7]. Vermicompost could release nutrients slowly and steadily into the system and enables the plants to absorb these nutrients over time [8]. Edwards [9] reported that vermicompost could promote early and vigorous growth of seedlings. Vermicompost has been found to effectively enhance the root formation, elongation of stem and production of biomass, vegetables, ornamental plants, etc. [5] [10]-[14]. More available plant nutrients and microbial metabolites may be released into the growth media because earthworms may stimulate microbial activities and metabolism and also influence microbial populations [15]. Edwards and Burrows [16] reported that animal waste vermicomposts usually contained more nutrient elements than chemical plant growth media and composts released nutrients gradually in available forms that could be readily taken up by the plants.

The objective of the present study was to compare the response of different doses of cow manure vermicompost and inorganic fertilizer on the growth and fruits of tomato plant.

\section{Materials and Methods}

\subsection{Plant Growth Experiment}

A greenhouse pot experiment was carried out in the Department of Soil Science, University of Chittagong, Bangladesh, using a sandy loam surface soil $(0-15 \mathrm{~cm})$. Soil sample was air dried and passed through a 4-mm sieve for using the soil in the pots for plant growth experiment. A sub sample was air dried and passed through a 2-mm sieve and stored for laboratory analysis, Soil $\mathrm{pH}$ of 5.07 was measured at 1:2.5 soil to water ratio, organic carbon of $0.93 \%$ was measured by Walkley and Black [17] and CEC of $4.01 \mathrm{cmol} \mathrm{kg}^{-1}$ was measured with $1 \mathrm{M} \mathrm{NH}_{4} \mathrm{OAc}$ extraction [18]. The percentages of sand (73\%), silt (13\%) and clay (14\%) were measured by hydrometer method [19]. The vermicompost used in this research was resulted from processing on the cow manure with the help of Eisenia fetida worms. The $\mathrm{pH}$ of vermicompost was of 8.23. Five rates of vermicompost equivalent to 0 (control), 5, 10, 15 and $20 \mathrm{t} \mathrm{ha}^{-1}$ and three rates of NPK fertilizers equivalent to 50\% (N-P-K $=69-16-35 \mathrm{~kg} \mathrm{ha}^{-1}$ ), 100\% $\left(\mathrm{N}-\mathrm{P}-\mathrm{K}=137-32-70 \mathrm{~kg} \mathrm{ha}^{-1}\right)$ and 200\% (N-P-K = 274-64-140 $\mathrm{kg} \mathrm{ha}^{-1}$ ) were applied separately in each pot containing four (4) $\mathrm{kg}$ soil. The pots were arranged in a completely randomized design (CRD) with three replications.

Twenty one (21) days old and uniform seedlings of tomato (Solanumly copersicum L.) having 2-3 leaves were transplanted to each pot. Water was applied to each pot regularly up to the field capacity. The height $(\mathrm{cm})$ and number of leaves of the plants were recorded at 15 days intervals after transplanting (15, 30, 45, 60 and 75 DAT). The number of fruit(s) were counted and weighed after harvesting. The plants were harvested at 75 DAT and separated into shoots and roots. The roots were cleaned carefully to remove adhering soil particles. The shoots and roots were air dried for several days and oven dried at $65^{\circ} \mathrm{C}$ for 72 hours and dry weights were recorded.

\subsection{Statistical Analysis}

Microsoft Excel and Minitab program [20] were used for analysis of variance (ANOVA).

\section{Results}

Application of different rates of vermicompost (5, 10, 15 and $20 \mathrm{tha}^{-1}$ ) and NPK fertilizer (50\%, 100\% and 200\%) in tomato plant significantly $(P<0.05)$ affected the growth and development of plants, number of fruits and mean fresh weight of fruit and yield during the study period of 75 days. 


\subsection{Effect of Vermicompost and NPK Fertilizer on Growth Parameters of Tomato}

\subsubsection{Shoot Length}

From 15 to 75 DAT, the plant height ranged from 11.0 to $32.0 \mathrm{~cm}$ in $5 \mathrm{t} \mathrm{ha}^{-1}$ and 13.33 to $52.67 \mathrm{~cm}$ in $20 \mathrm{t} \mathrm{ha}^{-1}$ of vermicompost. Whereas, at the same DAT, the plant height ranged from 12.0 to $24.33 \mathrm{~cm}$ in $50 \%$ and 14.67 to $39.67 \mathrm{~cm}$ in $200 \%$ of NPK fertilizer and from 10.33 to $16.33 \mathrm{~cm}$ in control treatment (Figure 1(a)). Significant increase were observed among different treatments for shoot length $(\mathrm{F}=70.41, P<0.001)$ during different growth intervals. At harvest, application of highest rate of vermicompost $\left(20 \mathrm{t} \mathrm{ha}^{-1}\right)$ and NPK fertilizer (200\%) showed an increase of $36.34 \mathrm{~cm}$ and $23.34 \mathrm{~cm}$ of shoot length respectively, as compared to control. Vermicompost dose of 20 $\mathrm{t}$ ha ${ }^{-1}$ resulted in maximum plant height of $52.67 \mathrm{~cm}$.

\subsubsection{Number of Leaves}

The number of leaves from 15 to 75 DAT ranged from 21 to 44 in $5 \mathrm{t} \mathrm{ha}^{-1}$ and 20 to 104 in $20 \mathrm{t} \mathrm{ha}^{-1}$ of vermicompost. Whereas, at the same DAT, the number of leaves ranged from 17 to 51 in $50 \%$ and 26 to 74 in $200 \%$ of NPK fertilizer and from 14 to 20 in control treatment (Figure 1(b)). The effect of application of vermicompost and NPK fertilizer was significant $(F=60.99, P<0.001)$ on the number of leaves among different treatments. At harvest, application of highest rate of vermicompost $\left(20 \mathrm{t}^{\mathrm{h}} \mathrm{a}^{-1}\right)$ and NPK fertilizer (200\%) showed an increase of 84 (4 folds) and 54 (3 folds) of leaves per plant respectively, as compared to control.

\subsection{Effect of Different Doses of Vermicompost and NPK Fertilizer on Yield Parameters of Tomato}

\subsubsection{Dry Shoot Weight}

Dry shoot weight ranged from $1.40 \mathrm{~g}$ in $5 \mathrm{t} \mathrm{ha}^{-1}$ to $4.25 \mathrm{~g}$ in $20 \mathrm{t} \mathrm{ha}^{-1}$ of vermicompost and $0.99 \mathrm{~g}$ in $50 \%$ to $2.90 \mathrm{~g}$ in 200\% of NPK fertilizer treated pots respectively, and in control it was $0.08 \mathrm{~g}$ (Figure 2(a)). There is a significant increase in dry shoot weight $(\mathrm{F}=135, P<0.001)$ among the treatments and the highest rate of vermicompost $\left(20 \mathrm{t} \mathrm{ha}^{-1}\right)$ and NPK fertilizer (200\%) resulted an increase in dry shoot weight in respective treatments by $4.17 \mathrm{~g}$ (52 folds) and $2.82 \mathrm{~g}$ ( 35 folds) as compared to control. However, vermicompost application at the rate of $15 \mathrm{tha}^{-1}$ showed better results $(3.61 \mathrm{~g})$ than the highest rate (200\%) of NPK fertilizer. The results of 5 and $10 \mathrm{t} \mathrm{ha}^{-1}$ of vermicompost were comparable with the results of $50 \%$ and $100 \%$ of NPK fertilizer treatments, respectively (Figure 2(a)).

\subsubsection{Dry Root Weight}

Dry root weight ranged from $0.91 \mathrm{~g}$ in $5 \mathrm{t} \mathrm{ha}^{-1}$ to $3.44 \mathrm{~g}$ in $20 \mathrm{tha}^{-1}$ of vermicompost and $0.76 \mathrm{~g}$ in $50 \%$ to $2.43 \mathrm{~g}$ in $200 \%$ of NPK fertilizer treated pots respectively, and in control it was $0.03 \mathrm{~g}$ (Figure 2(a)). There is a significant increase in dry root weight $(\mathrm{F}=582, P=0.000)$ among the treatments and the highest rate of vermicompost $\left(20 \mathrm{t} \mathrm{ha}^{-1}\right)$ and NPK fertilizer (200\%) resulted an increase in dry root weight in respective treatments by $3.41 \mathrm{~g}$ (115 folds) and $2.40 \mathrm{~g}$ (80 folds) as compared to control. However, vermicompost application at the rate of $15 \mathrm{t}$ $\mathrm{ha}^{-1}$ showed better results $(2.85 \mathrm{~g})$ than that of the highest rate of NPK fertilizer $(200 \%)$. The results obtained from the rate of 5 and $10 \mathrm{t} \mathrm{ha}^{-1}$ of vermicompost showed no significant difference $(P<0.05)$ with that of the results obtained from the rates of $50 \%$ and $100 \%$ of NPK fertilizer, respectively (Figure 2(b)).

\subsection{Effect of Different Doses of Vermicompost and NPK Fertilizer on Quantity of Fruit of Tomato}

\subsubsection{Number of Fruit(s)/Plant}

The numbers of fruit(s)/plant were ranged from 2 in $5 \mathrm{t} \mathrm{ha}^{-1}$ to 7 in t ha ${ }^{-1}$ of vermicompost and 1 in $50 \%$ to 4 in $200 \%$ of NPK fertilizer treated pots respectively, and in control it was $1 \mathrm{~g}$ (Figure 3(a)). Rates of vermicompost and NPK application has resulted in significant increase $(\mathrm{F}=20, P<0.001)$ in number of fruit(s)/plant and the increase in the highest rate of vermicompost $\left(20 \mathrm{t} \mathrm{ha}^{-1}\right)$ and NPK fertilizer (200\%) treatments was of 6 (6 folds) and 4 (4 folds) fruit(s)/plant as compared to control.

\subsubsection{Mean Fresh Fruit Weight}

Mean fresh fruit weight ranged from $7.9 \mathrm{~g}$ in $5 \mathrm{t} \mathrm{ha}^{-1}$ to $40 \mathrm{~g}$ in $20 \mathrm{t} \mathrm{ha}^{-1}$ of vermicompost and $6.1 \mathrm{~g}$ in $50 \%$ to $25 \mathrm{~g}$ 


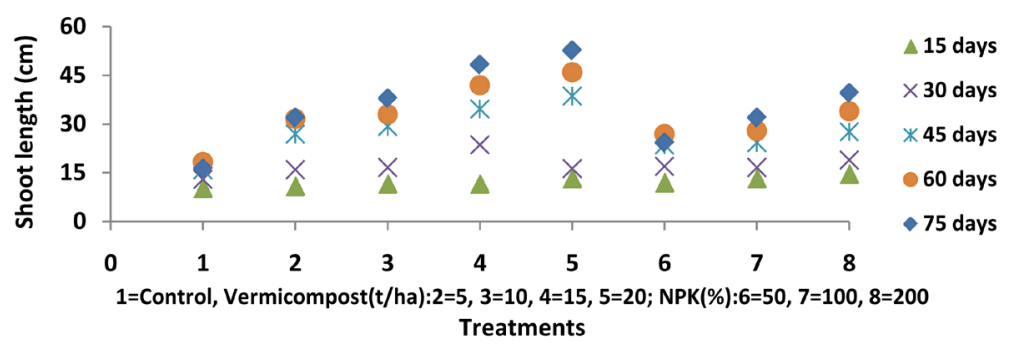

(a)

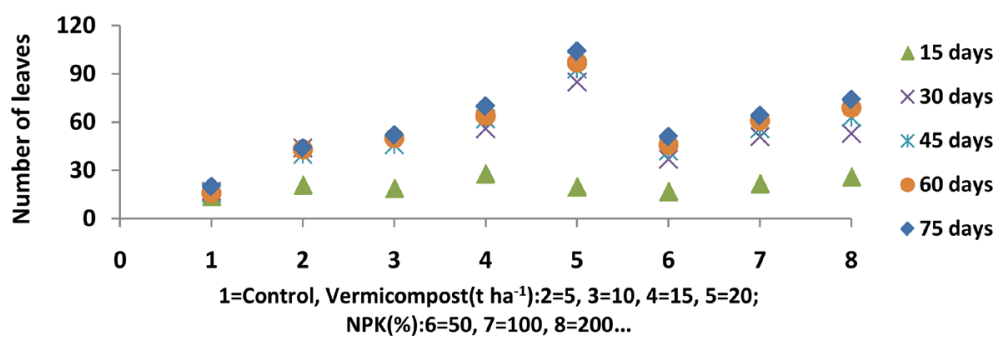

(b)

Figure 1. Application of vermicompost and inorganic fertilizer on growth parameters of tomato (Solanum lycopersicum L.) (mean \pm standard error).

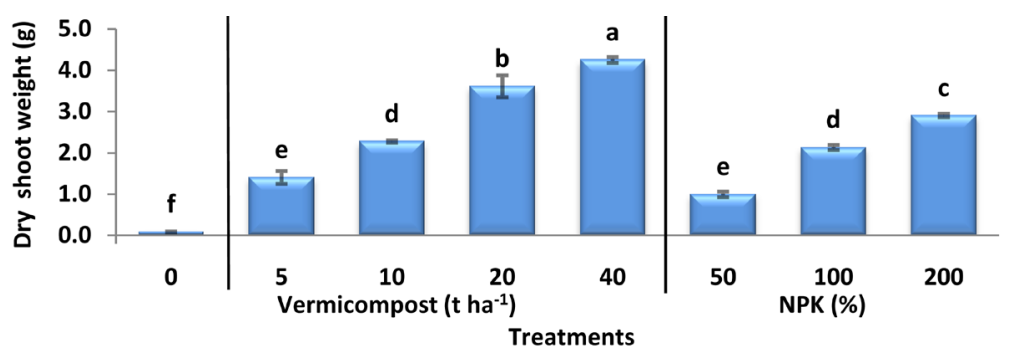

(a)

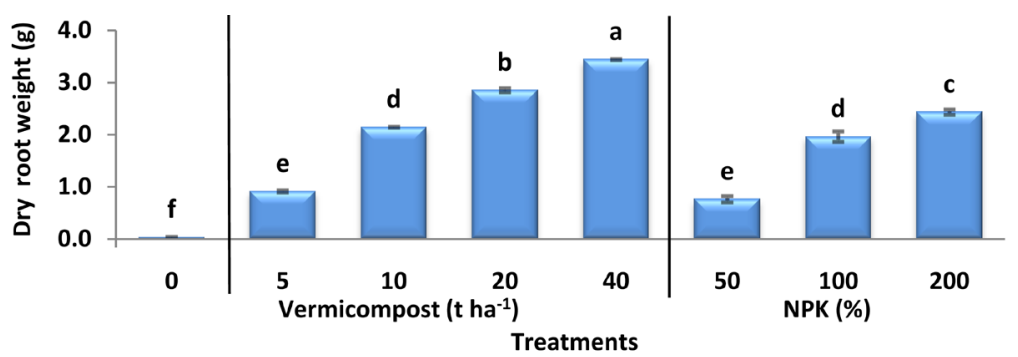

(b)

Figure 2. Application of vermicompost and inorganic fertilizer on dry shoot and root weight of tomato (Solanum lycopersicum L.) (mean \pm standard error).

in $200 \%$ of NPK fertilizer treated pots respectively, and in control it was $1.34 \mathrm{~g}$ (Figure 3(b)). There is a significant increase in mean fresh fruit weight $(\mathrm{F}=74, P<0.001)$ among the treatments and the highest rate of vermicompost $\left(20 \mathrm{t} \mathrm{ha}^{-1}\right)$ and NPK fertilizer (200\%) resulted an increase in mean fresh fruit weight in respective treatments by $39 \mathrm{~g}$ (29 folds) and $24 \mathrm{~g}$ (18 folds) as compared to control treatment.

\section{Discussion}

The results of this experiment showed that the treatments of vermicompost and NPK fertilizer significantly increased the production of tomato in pots. 


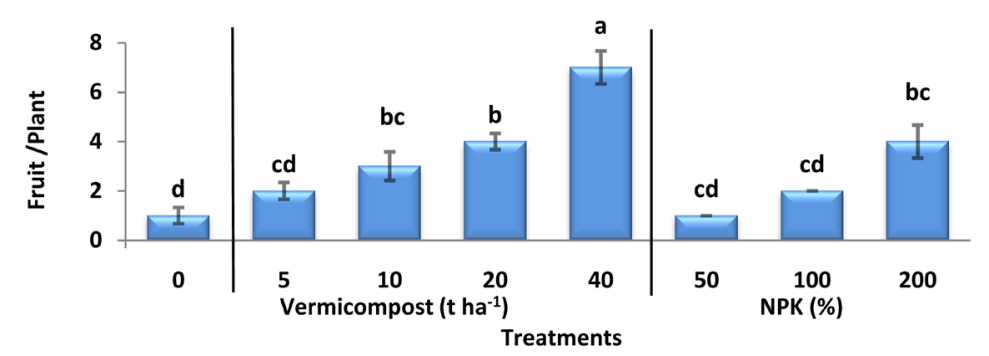

(a)

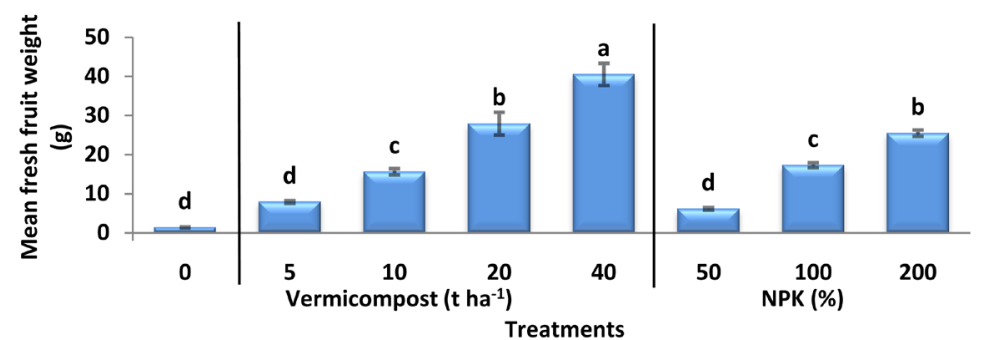

(b)

Figure 3. Application of vermicompost and inorganic fertilizer on number of fruit/plant and mean fresh fruit weight of tomato (Solanum lycopersicum L.) (mean \pm standard error).

Plant growth parameters such as shoot length, number of leaves, shoot and root dry weights, number of fruits and fresh fruit weight were better in vermicompost treated pots than the NPK fertilizer treated pots. Among the vermicompost rates, the $20 \mathrm{t} \mathrm{ha}^{-1}$ showed the highest response in tomato plants. The differential response of plants to different doses of vermicompost may be due to release of variable amount of available nutrients and growthpromoting substances [4] [5]. Our results corroborate with the findings of other investigators [4] [21] [22]. They [4] [21] [22] reported significant increase in growth parameters of plants after application of vermicompost in the growth media. Scientists of different agricultural fields agreed that plant growth and development are strictly dependent on biological fertility factors. Earthworms may stimulate microbial activities and metabolism and also influence microbial populations. As a consequence, more available nutrients and microbial metabolites are released into the soil [15].

Moreover, in terms of plant growth and soil health, vermicompost plays an important role in improving soil texture, aeration, soil compaction and thus enhances more water and nutrients uptake by plants from their surrounding areas of root zone. There is much evidence that the activity of earthworms accelerates organic matter mineralization, decomposition of polysaccharides, increase the humus in the soil, and oppositely reduce the availability of toxic heavy elements to plants [23]. Macronutrients play important role in crop yield based on their role in activation of enzymes for chlorophyll synthesis, growth, fruit ripening and maintenance of the plant's enzyme system [24]. Therefore, the use of vermicompost constitutes an important alternative source of fertilizer that has environmental benefits, productivity and crop quality as well as compared to inorganic fertilizer.

\section{Conclusion}

From our results, it can be concluded that cow manure vermicompost application to soil increased growth parameters and fruit numbers of tomato plants (Solanum lycopersicum L.) over the inorganic fertilizer (NPK fertilizer) and hence could be useful for different crops production instead of inorganic fertilizers. The use of cow manure vermicompost could be a better option and farmers need to be educated about the importance of vermicomposting. More field trials with different crops need to be conducted in the future.

\section{Acknowledgements}

The authors wish to express their warm gratitude to the Research and Planning Division of Chittagong University, Bangladesh, for providing fund through the University Grants Commission of Bangladesh (UGC) to conduct this research. 


\section{References}

[1] Inbar, Y., Hadar, Y. and Chen, Y. (1993) Recycling of Cattle Manure: The Composting Process and Characterization of Maturity. Journal of Environmental Quality, 22, 857-863. http://dx.doi.org/10.2134/jeq1993.00472425002200040032x

[2] Alam, M.N., Jahan, M.S., Ali, M.K., Islam, M.S. and Khandaker, S.M.A.T. (2007) Effect of Vermicompost and NPKS Fertilizers on Growth, Yield and Yield Components of Red Amaranth. Australian Journal of Basic and Applied Sciences, 1, 706-716.

[3] Rathier, T.M. and Frink. C.R. (1989) Nitrate in Runoff Water from Container-Grown Juniper and Alberta Spruce under Different Irrigation and N Fertilization Regimes. Journal of Environmental Horticulture, 7, 32-35.

[4] Tomati, U., Galli, E., Grappelli, A. and Di Lena, G. (1990) Effect of Earthworm Casts on Protein Synthesis in Radish (Raphanus sativum) and Lettuce (Lactuca sativa) Seedlings. Biology and Fertility of Soils, 9, 288-289. http://dx.doi.org/10.1007/BF00634102

[5] Grappelli, A., Tomati, U. and Galli, E. (1985) Earthworm Casting in Plant Propagation. Horticultural Science, 20, $874-876$.

[6] Chanda, G.K., Bhunia, G. and Chakraborty, S.K. (2011) The Effect of Vermicompost and Other Fertilizers on Cultivation of Tomato Plants. Journal of Horticulture and Forestry, 3, 42-45.

[7] Sajnanath, K. and Sushama, P.K. (2004) Recycling of Bio-Wastes through Vermicomposting. Agrobios News Letter, 3, 33-34.

[8] Sharma, A.K. (2003) Biofertilizers for Sustainable Agriculture. Updesh Purohit for Agrobios, Jodhpur, 41-46.

[9] Edwards, C.A. and Burrows, I. (1988) The Potential of Earthworm Composts as Plant Growth Media. In: Edwards, C.A. and Neuhauser, E.F., Eds., Earthworms in Environmental and Waste Management, SPB Academic Publishing, The Hague, 211-220.

[10] Kale, R.D. and Bano, K. (1986) Field Trials with Vermicompost (Vee Comp. E.83 UAS) an Organic Fertilizer. In: Dash, M.C., Senapati, B.K. and Mishra, P.C., Eds., Procedings of the National Seminar on Organic Waste Utilization, Vermicompost, Part B: Verms and Vermicomposting, Five Star Printing Press, Burla, 151-157.

[11] Kale, R.D., Bano, K., Sreenivasa, M.N. and Bagyaraj, D.J. (1987) Influence of Worm Cast (Vee Comp. E.83 UAS) on the Growth and Mycorrhizal Colonization of Two Ornamental Plants. South Indian Horticulture, 35, 433-437.

[12] Kale, R.D. (1998) Earthworm: Cinderella of Organic Farming. Prism Books, Bangalore.

[13] Bano, K., Kale, R.D. and Satyavathi, G.P. (1993) Vermicompost as Fertilizer for Ornamental Plants. In: Rajagopal, D., Kale, R.D. and Bano, K., Eds., Proceedings of 4th National Symposium on Soil Pleurotus ostreatus against Infectious Bursal Biology and Ecology, ISSBE, UAS, Bangalore, 165-168.

[14] Atiyeh, R.M., Subler, S., Edwards, C.A. and Metzger, J. (1999) Growth of Tomato Plants in Horticulture Potting Media Amended with Vermicompost. Pedobiologia, 43, 724-728.

[15] Tomati, U., Grapppelli, A. and Galli, E. (1988) The Hormone-Like Effect of Earthworm Casts on Plant Growth. Biology and Fertility of Soils, 5, 288-294. http://dx.doi.org/10.1007/BF00262133

[16] Edwards, C.A. (1988) Use of Earthworms in Breadown and Management of Organic Wastes. In: Edwards, C.A., Ed., Earthworm Ecology, CRC Press LLC, Boca Raton, 327-354.

[17] Walkley, A. and Black, I.A. (1934) An Examination of the Degtjareff Method for Determining Soil Organic Matter and a Proposed Modification of the Chromic Acid Titration Method. Soil Science, 37, 29-38. http://dx.doi.org/10.1097/00010694-193401000-00003

[18] Soil Survey Laboratory Staff (1992) Soil Survey Laboratory Methods Manual. Soil Survey Laboratory Investigations Report No. 42, USDA-SCS, Washington DC.

[19] Bouyoucos, G.J. (1962) Hydrometer Method Improved for Making Particle Size Analysis of Soils. Agronomy Journal, 54, 464-465. http://dx.doi.org/10.2134/agronj1962.00021962005400050028x

[20] Minitab, Inc. (1996) Minitab User Guide Release 11. Minitab, State College.

[21] Joshi, R. and Vig, A.P. (2010) Effect of Vermicompost on Growth, Yield and Quality of Tomato (Solanum lycopersicum L.). African Journal of Basic Applied Sciences, 2, 117-123.

[22] Bachman, G.R. and Metzger, J.D. (2008) Growth of Bedding Plants in Commercial Potting Substrate Amended with Vermicompost. Bioresource Technology, 99, 3155-3161.

[23] Dominguez, J., Edwards, C.A. and Subler, S. (1997) A Comparison of Vermicomposting and Composting. Biocycle, 38, 57-59.

[24] Grusak, M.A. and DellaPenna, D. (1999) Improving the Nutrient Composition of Plants to Enhance Human Nutrition and Health. Annual Review of Plant Physiology and Plant Molecular Biology, 50, 133-161.

http://dx.doi.org/10.1146/annurev.arplant.50.1.133 
Scientific Research Publishing (SCIRP) is one of the largest Open Access journal publishers. It is currently publishing more than 200 open access, online, peer-reviewed journals covering a wide range of academic disciplines. SCIRP serves the worldwide academic communities and contributes to the progress and application of science with its publication.

Other selected journals from SCIRP are listed as below. Submit your manuscript to us via either submit@scirp.org or Online Submission Portal.
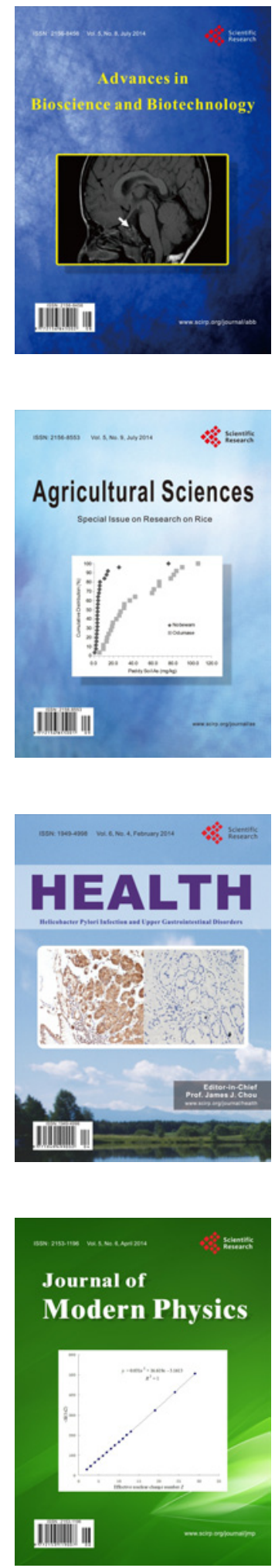
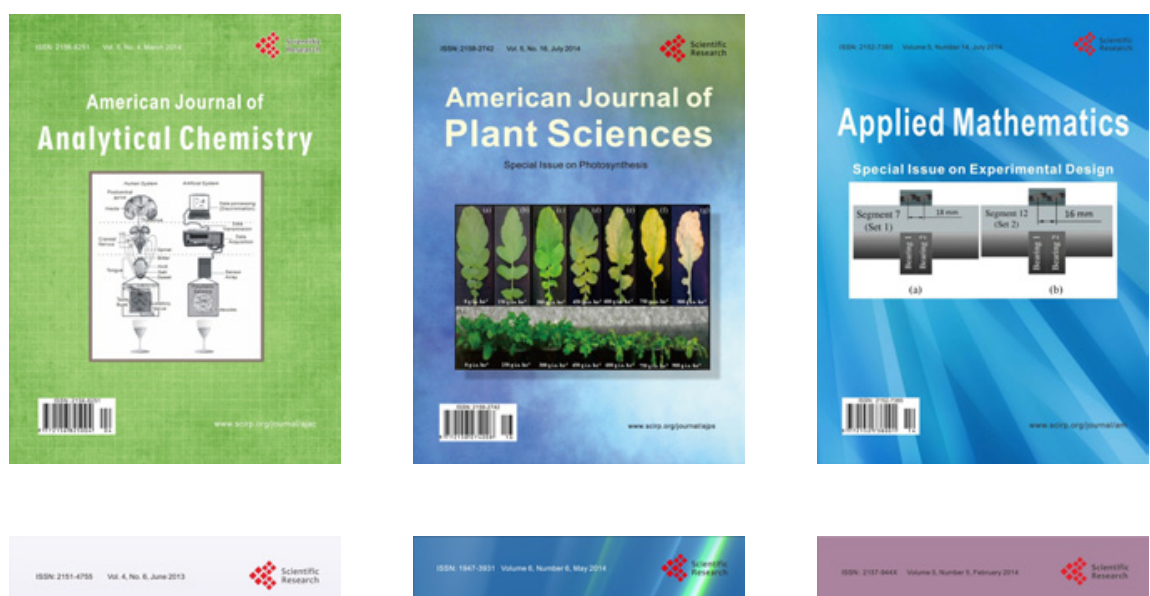

Creative Education
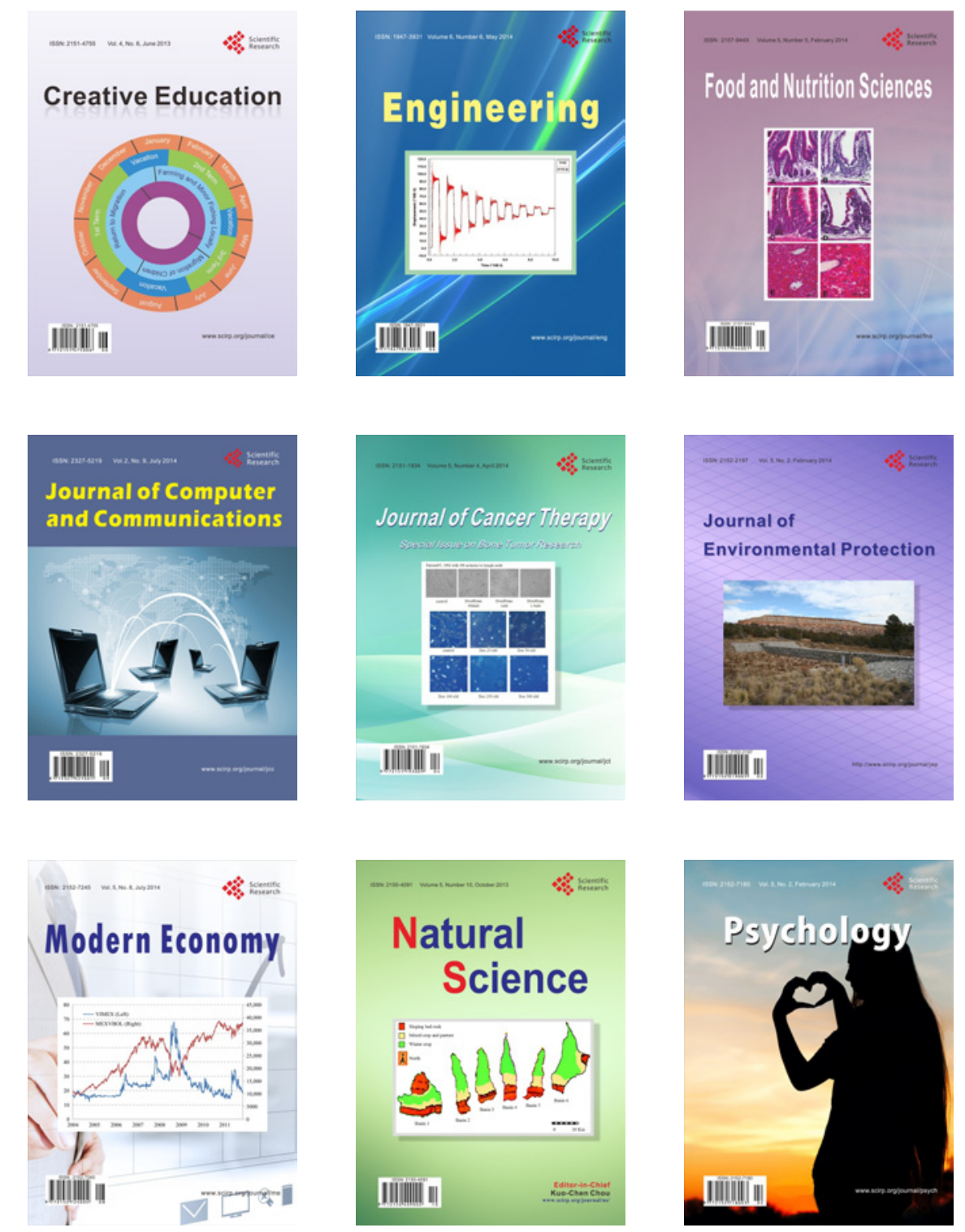